\title{
Demonstration by electron microscopy of pili on Gardnerella vaginalis
}

\author{
A P JOHNSON* AND H A DAVIEST \\ From the *Division of Sexually Transmitted Diseases and the + Electron Microscopy Research Group, \\ MRC Clinical Research Centre, Harrow, Middlesex HAI $3 J U$
}

SUMMARY Eight strains of Gardnerella vaginalis were examined by electron microscopy for the presence of pili. Narrow pili ranging from 3.0 to $7.5 \mathrm{~nm}$ in diameter were seen on bacteria from five of the strains studied.

\section{Introduction}

Gardnerella vaginalis is a Gram negative, catalase negative coccobacillus, ${ }^{1}$ which has been reported to colonise the lower genital tracts of men and women. In women the presence of the organism is particularly associated with signs and symptoms of non-specific vaginitis (NSV), ${ }^{2-4}$ although it has also been isolated from women not suffering from this complaint. ${ }^{5}$ Men colonised with this organism are usually asymptomatic. ${ }^{6}$

The biological features of $G$ vaginalis are not well characterised-for example, there are even conflicting reports as to whether the ultrastructure of the organism resembles that of Gram positive or Gram negative bacteria. ${ }^{78}$ In this study we investigated one facet of the biology of $G$ vaginalis, namely the presence or absence of pili (also called fimbriae) on the surface of the organisms.

\section{Materials and Methods}

BACTERIA

We studied eight strains of $G$ vaginalis (listed in the table), which were kindly supplied by Elizabeth Taylor of St Thomas's Hospital Medical School, London. The identification of these strains has been described in detail previously. ${ }^{1}$

NEGATIVE STAINING

Bacteria were cultured on Columbia blood agar plates (Difco, West Molesey, Surrey, UK) at $37^{\circ} \mathrm{C}$ in an atmosphere of $5 \%$ carbon dioxide in air for two days. Two methods of grid preparation were used. In

Address for reprints: Dr A P Johnson, Division of Sexually Transmitted Diseases, MRC Clinical Research Centre, Watford Road, Harrow, Middlesex HA1 3UJ

Accepted for publication 25 February 1984 the first (method A) the bacterial growth was scraped off the agar with a loop and suspended in $1 \%$ peptone water. Clumps of bacteria were then dispersed using a needle and syringe. A formvar/ carbon coated 400 mesh grid was floated on the surface of a drop of suspension of the organism for 1 minute, after which the edge was blotted. The second method (method B) was a modification of that used by Henrichsen and Blom $^{9}$ in which a drop of $1 \%$ peptone water was placed on the edge of a bacterial colony. A grid was then placed on this drop with the support film downwards for 10 seconds, removed, and the edge blotted. Grids prepared by either method were floated for two minutes on the surface of a drop of $3 \%$ glutaraldehyde in $0.1 \mathrm{~mol} / \mathrm{l}$ cacodylate buffer $(\mathrm{pH} \mathrm{7 \cdot 2)}$ containing $5 \%$ sucrose. Each grid was washed three times by being dipped into a drop of distilled water, blotted, then transferred on to a drop of $1 \%$ potassium phosphotungstate for 10 seconds. The grids were blotted and allowed to dry thoroughly before being examined using a Philips EM 300 electron microscope at $60 \mathrm{kv}$. To estimate the percentage of bacteria with pili, between 25 and 50 bacteria on each grid were examined. The diameters of pili were measured from micrographs using an eyepiece graticule.

\section{Results}

The table shows the presence or absence of pili on each of the eight strains of $G$ vaginalis. With three strains (67-1, 54-1, and 81-1) more than $10 \%$ of cells were pilated using both methods of grid preparation, while with two strains, (42-5 and 44-2) 6-10\% of cells showed pilation, but only by one of the two methods. Pili were not detected in the remaining three strains.

The number of pili per bacterial cell varied greatly from two to about 50 . In cells that were highly 
TABLE The degree of pilation exhibited by each of eight strains of Gardnerella vaginalis

$\%$ of bacteria with pili on grids prepared by:

\begin{tabular}{lll} 
Strain & Method $A^{*}$ & Method $B+$ \\
\hline $67-1$ & 18 & 54 \\
$54-1$ & 10 & 22 \\
$81-1$ & 12 & 12 \\
$42-5$ & 6 & $<2 \ddagger$ \\
$44-2$ & $<4 \S$ & 10 \\
$3-1$ & $<4$ & $<4$ \\
$39-2$ & $<4$ & $<4$ \\
$40-1$ & $<4$ & $<4$ \\
\hline
\end{tabular}

*Bacterial growth scraped off agar with loop and suspended in $1 \%$ peptone water; clumps of bacteria dispersed with needle and syringe and grid floated on suspension.

tDrop of $1 \%$ peptone water placed on edge of bacterial colony, and grid floated on this suspension.

$\$ 50$ bacteria examined. $\$ 25$ bacteria examined.

pilated, the distribution of pili was peritrichous (figure). When only a few pili were seen on cells, they were randomly distributed. The diameters of individual pili varied from 3.0 to $7.5 \mathrm{~nm}$, although in strain 67-1 some pili radiating from the cell surface were aggregated into bundles.

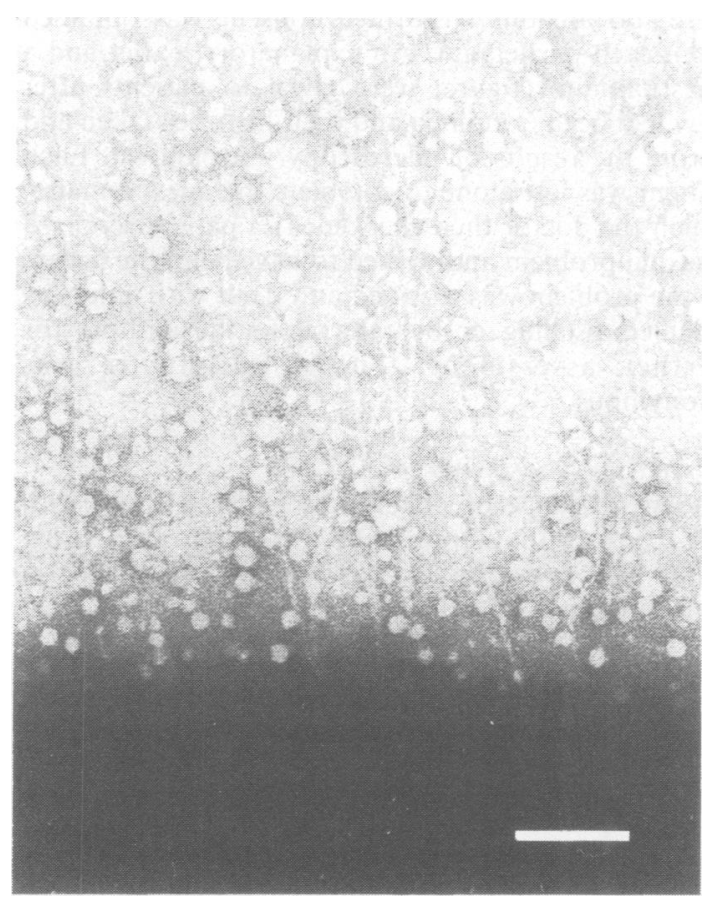

FIGURE Electron micrograph of a portion of a Gardnerella vaginalis organism with pili radiating from surface. $($ Bar $=100 \mathrm{~nm}$.)

\section{Discussion}

The results presented here show that $G$ vaginalis may now be added to the list of bacteria known to produce pili. In this study, however, both pilated and non-pilated strains were found, and in the pilated strains only a few of the bacterial cells expressed pili. One explanation for this may be that pili were possibly sheared off during preparation of the specimens for electron microscopy. This is suggested by the observation that samples prepared by the more gentle method (method B) tended to show a greater degree of pilation. Another explanation for the low level of pilation may be the fact that the strains had been subcultured several times before this study. A precedent for this idea comes from the observation that gonococci cease to express pili when nonselectively subcultured in the laboratory. ${ }^{10} \mathrm{~A}$ further consideration is that the conditions under which the organisms were cultured may not have been optimum for the production of pili. However, now that the presence of pili on $G$ vaginalis organisms has been shown, further studies to delineate factors that influence their production and a study of their potential biological properties, such as the ability to promote the attachment of the bacteria to eukaryotic cells, would seem to be warranted.

\section{References}

1. Taylor E, Phillips I. The identification of Gardnerella vaginalis. J Med Microbiol 1983; 16:83-92.

2. Gardner $\mathrm{HL}$, Dukes $\mathrm{CD}$. Haemophilus vaginalis vaginitis: a newly defined specific interaction previously classified "nonspecific" vaginitis. Am J Obstet Gynecol 1955;69:962-76.

3. Pheifer TA, Forsyth PS, Durfee MA, Pollock HM, Holmes KK. Nonspecific vaginitis: role of Haemophilus vaginalis and treatment with metronidazole. $N$ Engl J Med 1978; 298: 1429-34.

4. Taylor E, Blackwell AL, Barlow D, Phillips I. Gardnerella vaginalis, anaerobes and vaginal discharge. Lancet 1982; i: 1376-9.

5. McCormack WM, Hayes $\mathrm{CH}$, Rosner B, et al Vaginal colonization with Corynebacterium vaginale (Haemophilus vaginalis). $J$ Infect Dis 1977; 136: 740-5.

6. Dawson SG, Ison CA, Csonka G, Easmon CSF. Male carriage of Gardnerella vaginalis. Br J Vener Dis 1982; 58:243-5.

7. Reyn A, Birch-Andersen A, Lapage SP. An electron microscope study of thin section of Haemophilus vaginalis (Gardner and Dukes) and some possibly related species. Can J Microbiol 1966; 12:1125-36.

8. Criswell BS, Stenback WA, Black SH, Gardner HL. Fine structure of Haemophilus vaginalis. J Bacteriol 1972; 109: 930-2.

9. Henrichsen J, Blom J. Correlation between twitching motility and possession of polar fimbriae in Acinetobacter calcoaceticus. Acta Path Microbiol Scand 1975;83B: 103-15.

10. Jephcott AE, Reyn A, Birch-Andersen A. Neisseria gonorrhoeae III. Demonstration of presumed appendages to cells from different colony types. Acta Path Microbiol Scand 1971; 79B:437-9. 